\title{
Temperature Regulation of Primary and Secondary Seed Dormancy in Rosa canina L.: Findings from Proteomic Analysis
}

\author{
Tomasz A. Pawłowski *D, Barbara Bujarska-Borkowska, Jan Suszka, Tadeusz Tylkowski, \\ Paweł Chmielarz ${ }^{\mathbb{D}}$, Ewelina A. Klupczyńska and Aleksandra M. Staszak ${ }^{\mathbb{D}}$ \\ Institute of Dendrology, Polish Academy of Sciences, Parkowa 5, 62-035 Kórnik, Poland; \\ bbujarska@man.poznan.pl (B.B.-B.); jsuszka@man.poznan.pl (J.S.); ttylkows@man.poznan.pl (T.T.); \\ pach@man.poznan.pl (P.C.); evelin@man.poznan.pl (E.A.K.); staszak.a@gmail.com (A.M.S.) \\ * Correspondence: tapawlow@man.poznan.pl
}

Received: 16 June 2020; Accepted: 22 September 2020; Published: 23 September 2020

check for updates

\begin{abstract}
Temperature is a key environmental factor restricting seed germination. Rose (Rosa canina L.) seeds are characterized by physical/physiological dormancy, which is broken during warm, followed by cold stratification. Exposing pretreated seeds to $20^{\circ} \mathrm{C}$ resulted in the induction of secondary dormancy. The aim of this study was to identify and functionally characterize the proteins associated with dormancy control of rose seeds. Proteins from primary dormant, after warm and cold stratification (nondormant), and secondary dormant seeds were analyzed using 2-D electrophoresis. Proteins that varied in abundance were identified by mass spectrometry. Results showed that cold stratifications affected the variability of the highest number of spots, and there were more common spots with secondary dormancy than with warm stratification. The increase of mitochondrial proteins and actin during dormancy breaking suggests changes in cell functioning and seed preparation to germination. Secondary dormant seeds were characterized by low levels of legumin, metabolic enzymes, and actin, suggesting the consumption of storage materials, a decrease in metabolic activity, and cell elongation. Breaking the dormancy of rose seeds increased the abundance of cellular and metabolic proteins that promote germination. Induction of secondary dormancy caused a decrease in these proteins and germination arrest.
\end{abstract}

Keywords: dormancy; gene expression; germination; horticulture; proteins; reproduction; rose; seed

\section{Introduction}

Temperature has a major influence on seed dormancy and germination, as it is one factor coordinating plant development with climate variability [1]. Temperature signaling is transduced to plant physiology and genetics in a multidimensional manner [1]. Seed dormancy is an evolutionary, environmentally imprinted adaptive trait that prevents germination under unfavorable temperature conditions. If seeds able to germinate lose this ability due to stressful environmental conditions (e.g., too high temperatures), secondary dormancy is established [2]. Such seeds revert to dormancy and overlap until the following spring or longer, which is a beneficial process from a biological standpoint (seed banks) but undesirable from an economic one, e.g., in a nursery. For their germination, repeated stratification is needed, but this does not guarantee eventual success. Finch-Savage and Leubner-Metzger [3] suggested that primary dormancy correlates to slow seasonal change (temporal sensing), associated with cycling from deep to shallow dormancy to select the climate space for emergence and time of year. Seasonal temperature patterns regulate the cycle. Secondary dormancy correlates with a rapid response to the suitability of local conditions for germination 
and plant establishment (spatial sensing). Under natural conditions, such environment-controlled dormancy is manifested as dormancy cycling between seasons and years [4].

Germination cueing can be a specified form of phenological cueing, since some environmental conditions must appear to break dormancy, and additional environmental conditions must occur to enable germination after dormancy is broken [5]. When seeds lose dormancy, the range of environmental conditions in which they can germinate broadens, and as secondary dormancy appears, that range narrows again [5]. Thus, the pace of primary dormancy loss, secondary dormancy introduction, and the attributes of temperature-dependent germination regulate not only the season but the long-term life history that is expressed.

For seeds of many plant species, the breaking of dormancy is not a quick change between dormant and nondormant states, but a series of continuous changes in the entire seed to the molecular level, from complete dormancy to complete nondormancy [6]. How this complicated system is used by the seed to adjust dormancy cycling in fluctuating environments is still unknown [7]. Information regarding seed dormancy and annual seasonal changes in the germination capacity of seeds may be advantageous to researchers in determining the best study pathways.

Physiological, molecular, and genetic analyses have provided insights into the mechanisms of seed dormancy and germination [8,9]. Plant hormones, including ABA, GA, auxin, or ethylene, are implicated in the regulation of dormancy status, including secondary dormancy [10-16]. The results of Footitt et al. [4] indicated that soil temperatures trigger seed-specific temporal sensing via the accumulation of DOG1 protein to drive changes in germination potential. Dormancy cycling is regulated by clock genes and the dormancy-related genes DOG1, mother of flowering time (MFT), CBL-interacting protein kinase 23 (CIPK23), and phytochrome A (PHYA) [17]. DOG1 participates in the induction of primary dormancy in response to cold maturation temperature acting on maternal plants and also participates in secondary dormancy in response to warm and cold stratification $[5,18]$. As DOG1-imposed dormancy alters responses to germination temperatures, DOG1 strongly influences the environmental responsiveness of germination. Chiang et al. [19] considered the timing of germination, and particularly DOG1-controlled dormancy, to be associated with life-history alteration.

Wild rose seeds are characterized by the occurrence of combinational dormancy, which consists of physiological dormancy of the embryo and physical dormancy associated with seed coat properties [20]. This type of physical/physiological dormancy is broken during warm, followed by cold stratification $\left(25^{\circ} \mathrm{C} / 3^{\circ} \mathrm{C}\right)$ lasting several months [21]. A temperature of $20^{\circ} \mathrm{C}$ used on pretreated seeds caused the induction of secondary dormancy. Hilhorst [22] characterized secondary dormancy as a phenomenon that occurs after seed dispersal and the loss of primary dormancy. Edwards et al. [23] suggested that seeds must have some degree of primary dormancy to be capable of entering secondary dormancy.

In this study, we investigate how temperature affects proteome changes in Rosa canina seeds during primary dormancy release by warm and cold stratification and secondary dormancy induction by warm treatment. We hypothesized that there are certain similarities between the regulation of primary and secondary dormancy of seeds. One goal of the present study is to reveal differentially abundant proteins to identify those putatively responsible for the breaking of primary dormancy and induction of secondary dormancy of rose seeds.

\section{Results and Discussion}

The dormancy cycling phenomenon has been widely studied, but the molecular mechanism responsible remains largely unknown. Recent transcriptomic studies indicate that seeds vary and remain active at a molecular level in both primary and secondary dormancy $[13,16,24-26]$. Despite the many studies of primary dormancy proteomics, not one has considered secondary dormancy. In the present research, the main focus was on secondary dormancy to reveal proteins responsible for its control. We hypothesized, however, that there are certain similarities between the regulation of primary and secondary dormancy of seeds. Wild rose seeds were chosen as an object of study because of the practical difficulty in seed germination and emergence in field conditions corresponding to the 
undesirable trait of warm temperature-induced secondary dormancy. We observed that rose seed combinational dormancy was broken during warm $\left(25^{\circ} \mathrm{C}, 16\right.$ weeks) followed by cold stratification $\left(3{ }^{\circ} \mathrm{C}, 22\right.$ weeks). Pretreated seeds were exposed to a temperature of $20^{\circ} \mathrm{C}$ to induce secondary dormancy, in contrast to $3{ }^{\circ} \mathrm{C}$, which promoted germination (Figure 1). At $20^{\circ} \mathrm{C}$, seed germination for lot No. 1 reached only $3.5 \%$, lot No. $2,6.0 \%$, and lot No. 3, $18.5 \%$. Germination ability at $3{ }^{\circ} \mathrm{C}$ reached $58.5 \%, 80.5 \%$, and $92,0 \%$, respectively. Seed germination was dependent on individual variability (seed lot origin from a different shrub).

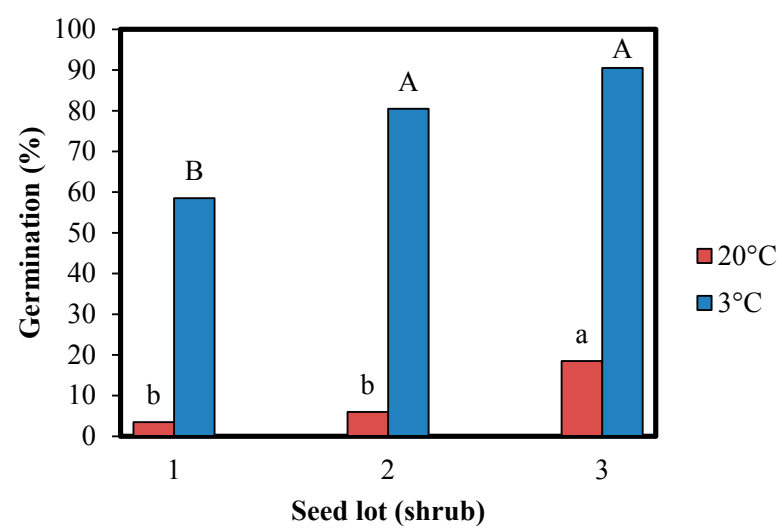

Figure 1. Effect of temperature on Rosa canina L. seed germination after dormancy breaking by warm/cold stratification $\left(16\right.$ weeks at $25{ }^{\circ} \mathrm{C}$ followed by 22 weeks at $3{ }^{\circ} \mathrm{C}$ ). Germination tests were performed for 8 weeks at 3 and $20^{\circ} \mathrm{C}$. Seeds were collected from three different shrubs (1-3). Data with different letters (lowercase for $20^{\circ} \mathrm{C}$ and capital for $3{ }^{\circ} \mathrm{C}$ ) are significantly different, $p<0.05$ (ANOVA and a Tukey-Kramer HSD).

For further proteomic investigations, seeds were taken from three seed lots from four time points: dry seeds (primary dormant), seeds after the warm phase of stratification, seeds after the cold phase of stratification (nondormant seeds), and seeds after germination testing at $20{ }^{\circ} \mathrm{C}$ with induced secondary dormancy (Figure S1). An average of 543 Coomassie blue-stained spots were detected on each two-dimensional gel representing each sample using the Image Master 7 Platinum program. A total of 16 spots exhibiting significant changes in abundance for temperature and origin, representing approximately $3 \%$ of the total number of spots on a reference gel (Figure 2) were identified by MS (Table 1).

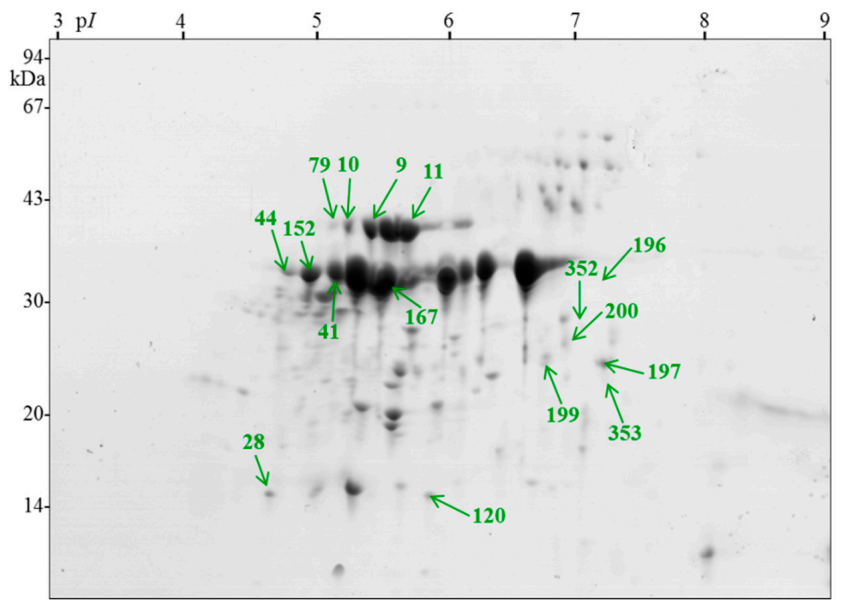

Figure 2. Reference gel demonstrating positions of statistically significantly variable spots from Rosa canina L. between dry seeds (primary dormant), seeds after warming, seeds after the cold phase of stratification (nondormant), and seeds after germination test at $20^{\circ} \mathrm{C}$ (secondary dormant). The numbers of identified proteins correspond to those listed in Table 1. 
Table 1. Identification of differentially abundant proteins of Rosa canina L. seeds during primary dormancy release by warm $\left(25^{\circ} \mathrm{C}\right)$ and cold $\left(3{ }^{\circ} \mathrm{C}\right)$ stratification and secondary dormancy induction by warm treatment $\left(20^{\circ} \mathrm{C}\right)$.

\begin{tabular}{|c|c|c|c|c|c|c|c|c|c|c|c|}
\hline \multirow[t]{2}{*}{ Spot $^{\mathrm{a}}$} & \multirow[t]{2}{*}{ Protein $^{\mathrm{b}}$ [Species] } & \multirow[t]{2}{*}{ Accession $^{c}$} & \multicolumn{2}{|c|}{ Theoretical } & \multicolumn{3}{|c|}{ Experimental Score } & \multirow[t]{2}{*}{$S C^{d}$} & \multirow[t]{2}{*}{ All/No Repeat ${ }^{\mathrm{e}}$} & \multirow[t]{2}{*}{ Unic/No Repeat ${ }^{\mathrm{f}}$} & \multirow[t]{2}{*}{ emPAI ${ }^{8}$} \\
\hline & & & MW & $\mathrm{p} I$ & MW & $\mathrm{p} I$ & & & & & \\
\hline 9 & succinyl-CoA ligase beta subunit [Arabidopsis thaliana] & AAM65138.1 & 46 & 6.1 & 40 & 5.3 & 166 & 5 & $3 / 3$ & $3 / 3$ & 0.2 \\
\hline 10 & actin [Lycoris longituba] & AFP44112.1 & 42 & 5.3 & 41 & 5.3 & 751 & 29 & $11 / 9$ & $0 / 0$ & 1.72 \\
\hline 11 & elongation factor E1 [Brassica oleracea var. capitata] & AFL69959.1 & 49 & 6.1 & 40 & 5.3 & 725 & 21 & $10 / 9$ & $9 / 8$ & 0.98 \\
\hline 28 & temperature-induced lipocalin [Solanum tuberosum] & АВB02386.1 & 21 & 6.0 & 16 & 4.9 & 118 & 10 & $2 / 2$ & $2 / 2$ & 0.48 \\
\hline 41 & legumin B-like [Fragaria vesca subsp. vesca] & XP_004294115.1 & 57 & 6.8 & 36 & 5.2 & 483 & 16 & $31 / 6$ & $16 / 3$ & 0.56 \\
\hline 44 & adenosine kinase 2 [Glycine soja] & KHN02332.1 & 38 & 5.5 & 37 & 5 & 99 & 3 & $1 / 1$ & $1 / 1$ & 0.12 \\
\hline 79 & actin-7 [Musa acuminata subsp. malaccensis] & XP_009383456.1 & 42 & 5.3 & 41 & 5.2 & 350 & 16 & $5 / 5$ & $0 / 0$ & 0.65 \\
\hline 120 & cytosolic class I small heat-shock protein HSP17.5 [Rosa hybrid cultivar] & ABO84841.1 & 17 & 6.0 & 15 & 5.8 & 562 & 46 & $16 / 8$ & $2 / 2$ & 5.64 \\
\hline 152 & mitochondrial ADP/ATP translocator [Chlamydomonas incerta] & ABA01103.1 & 34 & 9.7 & 37 & 5.0 & 357 & 15 & $5 / 5$ & $1 / 1$ & 0.86 \\
\hline 167 & legumin B-like [F. vesca subsp. vesca] & XP_004294115.1 & 57 & 6.3 & 36 & 5.5 & 493 & 16 & $40 / 6$ & $13 / 3$ & 0.56 \\
\hline 196 & 2-dehydro-3-deoxyphosphooctonate aldolase 1 [F. vesca subsp. vesca] & XP_004306551.1 & 32 & 6.6 & 32 & 6.1 & 590 & 33 & $9 / 8$ & 9/9 & 2.24 \\
\hline 197 & ATPase alpha subunit, partial (mitochondrion) [Chlorokybus atmophyticus] & ABI54626.1 & 38 & 9.3 & 24 & 7 & 131 & 5 & $2 / 2$ & $2 / 2$ & 0.12 \\
\hline 199 & triosephosphate isomerase, cytosolic [Zea mays] & ACG24648.1 & 27 & 5.5 & 23 & 6.6 & 283 & 14 & $3 / 3$ & $1 / 1$ & 0.58 \\
\hline 200 & triosephosphate isomerase, cytosolic [Z. mays $]$ & ACG24648.1 & 27 & 5.5 & 25 & 6.8 & 374 & 19 & $4 / 4$ & $2 / 2$ & 0.85 \\
\hline 352 & glyceraldehyde 3-phosphate dehydrogenase [R. multiflora] & AEQ75490.1 & 37 & 7.7 & 27 & 6.9 & 562 & 33 & $11 / 10$ & $1 / 1$ & 1.51 \\
\hline 353 & oil body-associated protein $1 \mathrm{~A}-$-like $[R$. chinensis $]$ & XP_024167493.1 & 27 & 5.9 & 26 & 7.1 & 408 & 19 & $6 / 5$ & $5 / 4$ & 1.19 \\
\hline
\end{tabular}

${ }^{a}$ The spot number is as indicated on the 2-D gels (Figure 2). ${ }^{b}$ The proteins identified in the present study. Protein identification was based on the best hit in a MASCOT search against NCBI databases. ${ }^{c}$ NCBI accession numbers. ${ }^{d}$ Percentage of sequence coverage. ${ }^{\mathrm{e}}$ The number of all nonredundant peptides for each protein spot. ${ }^{\mathrm{f}}$ The number of unique to nonredundant sequences within a unique peptide number. ${ }^{\mathrm{g}}$ exponentially modified protein abundance index (emPAI) estimate the absolute protein amount in proteomics by the number of sequenced peptides per protein [27]. 
As listed in Table 1, all 16 spots represented 14 nonredundant proteins. The various spots identified as the same protein (spots 41 and 167 as well as 199 and 200) could correspond either to post-translational modification (PTM) of the same protein or to various isoforms. The percentage of sequence coverage ranged from 5 to $46 \%$, and the number of identified peptides varied from 1 to 40 . Among the 16 spots, four corresponded to the Rosa genus, three to Fragaria vesca (Rosaceae family), and nine to other plants. Homologous proteins were found for all of the spots.

Among the 16 identified proteins, 12 showed variability in abundance for temperature (Table 2), six for origin, and two for both (ANOVA, the Tukey-Kramer HSD test, $p<0.05$ ). The temperature-induced secondary dormancy of rose seeds had an impact on the variability of six proteins compared to control, two proteins compared to warm stratification, and one protein compared to cold stratification (Table 2). Eight proteins were variable for cold stratification compared to dry seeds, and two proteins compared to warm stratification. Five proteins were variable for warm stratification compared to dry seeds (Table 2).

Table 2. The abundance of identified proteins of Rosa canina L. seed that significantly changed during primary dormancy release by warm $\left(25^{\circ} \mathrm{C}\right)$ and cold $\left(3^{\circ} \mathrm{C}\right)$ stratification and secondary dormancy induction by warm treatment $\left(20^{\circ} \mathrm{C}\right)$.

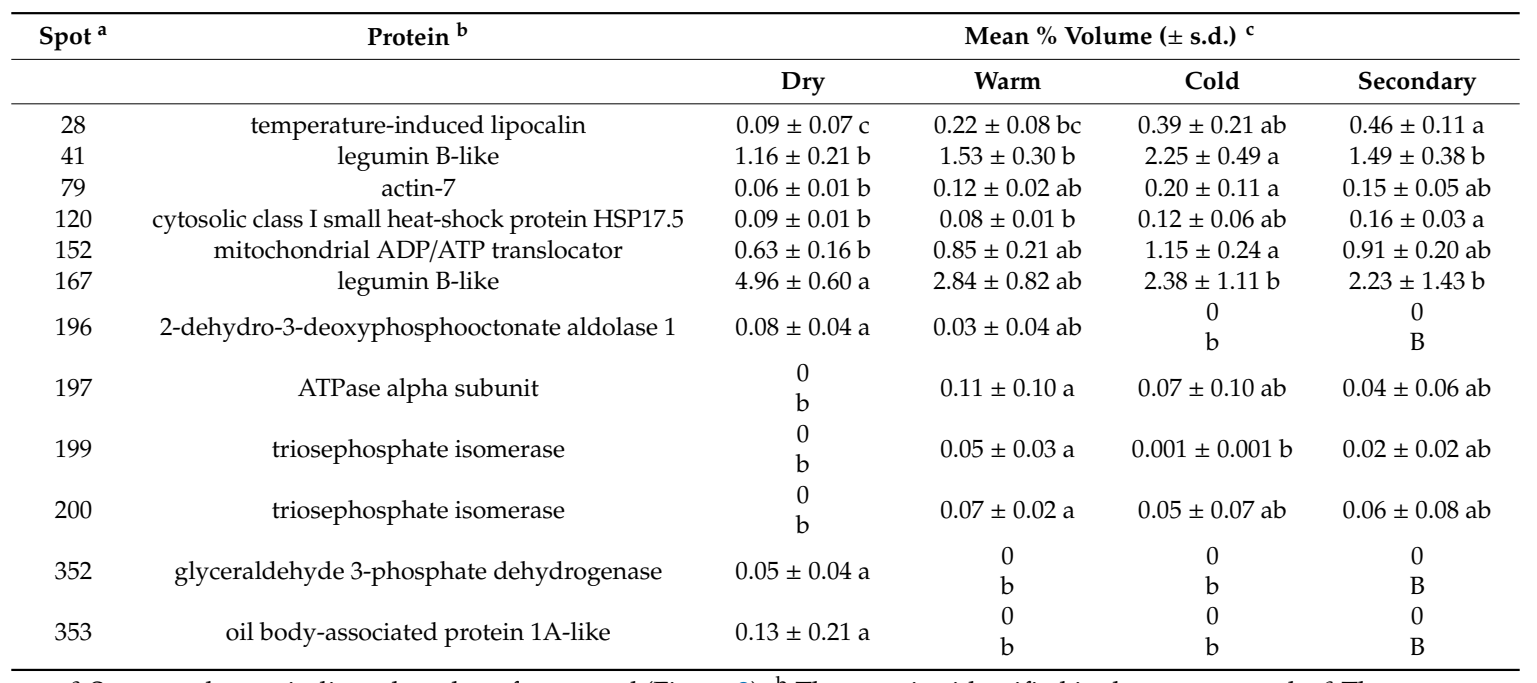

${ }^{a}$ Spot number, as indicated on the reference gel (Figure 2). ${ }^{\mathrm{b}}$ The proteins identified in the present study. ${ }^{\mathrm{c}}$ The mean value with the standard deviation of six spot volumes at each analyzed stage: dry, stratified seeds at 25 (warm), and $3{ }^{\circ} \mathrm{C}$ (cold) and seeds being under secondary dormancy after germination test at $20^{\circ} \mathrm{C}$. Spots were subjected to ANOVA and Tukey-Kramer HSD test to select spots that significantly varied $(p<0.05)$ in abundance. Levels not represented by the same letter are significantly different.

Here, we discuss the role of the proteins (due to the function and their related metabolic pathways) that can contribute to the dormancy status of the seeds in relation to system biology approaches [28].

Seed dormancy breaking and germination is a multifaceted process, associated with changes in the gene expression, protein synthesis, and physiology, but also with organelle functioning [29-31]. Numerous mitochondrial proteins have been identified as being involved in respiration, tricarboxylic acid (TCA) cycle, metabolism, import, and stress response as potentially important for seed germination [32,33]. Eight rose seed proteins identified in the present study (they are involved in glycolysis, TCA cycle, ATP synthesis, translation, stress response, cell activity, and transport) were predicted to be localized in mitochondria. This data confirms the link between mitochondrial functioning and the regulation of seed germination.

Legumin B-like protein (spots 167 and 41, decreased during secondary dormancy in comparison to dry seeds and cold stratification, respectively) is a plant seed storage protein, whose dominant function appears to be as a major nitrogen source for the developing plant [34]. Legumins accumulate gradually throughout maturation concomitantly with ABA [35]. They are present in dry seeds, essentially in cotyledons and hypocotyls, but disappear during their germination [36,37]. The decrease of this 
protein observed in the present study indicates the consumption of storage materials necessary for seed dormancy breaking and germination and also for the initiation of secondary dormancy. Consumption of storage materials can cause difficulty in the breaking of rose seed secondary dormancy.

Actin-7 (spot 79, increased during primary dormancy breaking in comparison to dry seeds) is associated with the regulation of hormone-induced plant cell proliferation and callus formation [38]. Accumulation of actin-7, as well as legumin, corresponded with the reserve deposition phase in Medicago truncatula seeds [39]. Actins, including actin-7, play an essential role in germination and root growth [40-44]. Actin-depolymerizing factor 2 (ADF2) proteins involved in a dynamic change in the cytoskeleton necessary for embryo cell elongation increased in abundance in germinated seeds but not in ungerminated thermoinhibited seeds [45]. The increase in abundance of actin-7 was observed in rose seeds after warm and cold stratification, proving its role in germination. Entrance into secondary dormancy decreased actin-7 abundance, likely suggesting its depolymerization and inhibition of cell elongation.

Mitochondrial ADP/ATP translocator (ADP/ATP carrier 3, AAC3 Arabidopsis homolog, spot 152, increased during primary dormancy breaking in comparison to dry seeds) catalyzes the exchange of cytosolic ADP with matrix ATP across the mitochondrial membrane and, thus, enables the mitochondria to supply energy to the cytosol, and subsequently to other organelles [46]. Adenine nucleotide transporters were indicated to be crucial for growth, as well as for photorespiratory metabolism, and accumulation of proteins and storage lipids [47-49]. The in silico analysis of the expression of adenine nucleotide carriers showed that they are variable under various stress conditions [47]. The AAC3 expression under stress conditions corresponds to genes associated with processes that rely on ATP-dependent enzymes of protein degradation pathways, such as ubiquitin-associated proteins [47]. A decrease in $A A C 3$ expression was indicated after seed imbibition; however, it reached a higher level in germinated seeds and seedlings $[47,50,51]$. The role of ADP/ATP carriers in seed germination can be associated with the change of quiescent mitochondria into active forms by providing ATP for actin activity [52].

The ATPase alpha subunit (ATPA, spot 197) forms a catalytic core of ATP synthase, which synthesizes ATP from ADP [53]. Energy in the form of ATP is needed for seed germination because germinating seeds lack both mineral uptake and photosynthetic systems [54]. The expression trend of the ATP synthase beta subunit showed an up-regulated pattern and demonstrated that energy metabolism continuously bolstered the process of germination [55]. The increase in activity of ATPases was observed during dormancy breaking of several tree seeds caused by cold stratification [40,56-58]. The present study demonstrated that the ATPase alpha subunit was up-accumulated during dormancy release of rose seeds, but this was observed only during warm stratification. Similarly, accumulation of triosephosphate isomerase (spots 199 and 200), a key enzyme in glycolysis, was shown to increase only during the warm phase of primary dormancy breaking. It seems that these enzymes are crucial for the warm phase of dormancy breaking because they provide adequate cellular ATP and carbohydrate metabolism levels.

Elongation factor E1 (EF E1, spot 11) participates in the process of mitochondrial biogenesis and has been stress-induced by salinity in lupine embryos [59]. Alterations in the accumulation level of mitochondrial elongation factor Tu (homolog of EF E1) were observed in Glycine max seeds during imbibition [60]. The changes in the abundance of elongation factors were indicated prior to seed germination and were associated with the beginning of mitotic activity [61]. High expression of EF is necessary for the preservation of rapid protein synthesis and cell division in meristematic tissues, which is fundamental for seed dormancy breaking and germination [61]. EF E1 accumulated in rose seeds during primary dormancy breaking and induction of secondary dormancy on a similar level, suggesting its general engagement in protein synthesis. 


\section{Materials and Methods}

\subsection{Plant Material}

Fully maturated seeds in nuts of the wild rose (Rosa canina L.) were collected in November 2015 from two proveniences: in Kobylepole near Poznań (lots no. 1 and 2 from two different shrubs, Poland, $52^{\circ} 23^{\prime} \mathrm{N}$ and $17^{\circ} 01^{\prime} \mathrm{E}$ ) and in Pokrzywno (lot no. 3 from one shrub, Poland, 52 $21^{\prime} \mathrm{N}$ and $16^{\circ} 58^{\prime} \mathrm{E}$ ). The seeds were separated from the fruit and dried for 10 days at room temperature to $9 \%$ moisture content. For further experiments, intact seeds were collected.

\subsection{Seed Germination}

Seed stratification was started in November 2015 (Figure S1). The stratification substrate was composed of quartz sand and peat ( $\mathrm{pH}$ 5.5-6.5). During stratification, the water content of seeds and substrate was controlled every week to aerate the seeds and replenish water losses. After 16 weeks of the warm phase $\left(25^{\circ} \mathrm{C}\right)$, seeds were transferred to the cold phase $\left(3^{\circ} \mathrm{C}\right)$ for 22 weeks. Those treatments break dormancy and promote seed germination. Subsequently, one portion of stratified seeds was subjected to the germination test at $3{ }^{\circ} \mathrm{C}$ temperature, which promotes seed germination. For the second portion the germination test was performed at $20^{\circ} \mathrm{C}$, a temperature which induces secondary dormancy. Germination tests were performed in 4 replicates of 50 seeds each for 8 weeks. Analysis of variance (ANOVA) and a Tukey-Kramer HSD were used to assess the influence of temperature on the level of seed germination, at $p<0.05$ (JMP software, SAS Institute, Cary, NC, USA).

For further proteomic investigations, seeds were collected from three seed lots from four time points: dry seeds (primary dormant), seeds after the warm phase of stratification, seeds after the cold phase of stratification (nondormant seeds), and seeds after germination testing at $20{ }^{\circ} \mathrm{C}$ with induced secondary dormancy.

\subsection{Proteome Analysis}

The seeds were mechanically crushed and ground into powder in a mortar cooled with liquid nitrogen. Proteins of powdered seeds were precipitated for 1 hour at $-20{ }^{\circ} \mathrm{C}$ in a $10 \%(w / v)$ solution of trichloroacetic acid (TCA) in acetone containing $20 \mathrm{mM}$ dithiothreitol (DTT) [57]. After centrifugation and vacuum drying, the resulting pellets were resuspended in lysis buffer (7 M urea, $2 \mathrm{M}$ thiourea, $2 \%$ (w/v) 3-([3-cholamidopropyl] dimethylammonio)-1-propanesulfonate (CHAPS), 1.5\% (w/v) DTT, 0.5\% $(v / v)$ immobiline polyacrylamide gel (IPG) buffer $\mathrm{pH} 3-10)$, supplemented with a protease inhibitor cocktail (Roche, Basel, Switzerland). Protein concentrations were determined using the Bradford assay [62]. Three replicates of 60 seeds were analyzed for each time point and seed lot.

Proteins were first separated electrophoretically on immobiline dry strips $(24 \mathrm{~cm}, \mathrm{pH} 3-10)$ using an Ettan IPGphor 3 IEF System (GE Healthcare, Little Chalfont, UK) according to the manufacturer's instructions. The strips were then equilibrated with solution I (6 M urea, $1.5 \mathrm{M}$ Tris- $\mathrm{HCl}, \mathrm{pH}$ 8.8, 30\% (v/v) glycerol, 2\% (w/v) SDS, 1\% (w/v) DTT) and solution II (solution I without DTT, supplemented with $2.5 \%(w / v)$ iodoacetamide). EttanDALT12.5\% $(w / v)$ polyacrylamide precast gels and Ettan DALT Six electrophoretic chamber (GE Healthcare, Little Chalfont, UK) were used for second-dimension electrophoresis (SDS-PAGE). Triplicate gels were run for every sample (biological replicates). After electrophoresis, the gels were stained with colloidal Coomassie blue [63], scanned, and analyzed using 2D Image Master 7 Platinum software (GE Healthcare, Little Chalfont, UK). After spot detection, 2D gels were aligned and matched, and normalized spot volumes were determined quantitatively. For each matched spot, the percent volume (abundance) was calculated as the volume divided by the total volume of matched spots. The spots showing variations in abundance were subjected to ANOVA and a Tukey-Kramer HSD test (JMP software, SAS Institute, Cary, NC, USA) to select spots significantly variable in abundance during maturation $(p<0.05)$. These proteins were identified by mass spectrometry (MS). 
Proteins were subjected to a standard "in-gel digestion" procedure [64]. Peptide mixtures were separated by liquid chromatography (LC) before molecular mass measurements (LC coupled to an LTQ-FTICR mass spectrometer) on an Orbitrap Velos mass spectrometer (Thermo Electron Corp., San Jose, CA, USA) at the Mass Spectrometry Laboratory (Institute of Biochemistry and Biophysics, Polish Academy of Sciences, Warsaw, Poland). A peptide mixture was applied to an RP-18 pre-column, then transferred to a nano-HPLC RP-18 column (Waters, Milford, MA, USA). The column outlet was directly coupled to the electrospray ionization (ESI) ion source of an Orbitrap Velos mass spectrometer (Thermo Electron Corp., San Jose, CA, USA), working in the regime of the data-dependent MS to MS/MS switch. An electrospray voltage of $1.5 \mathrm{kV}$ was used.

Acquired data were pre-processed with Mascot Distiller software (ver. 2.3.2.0, Matrix Science, London, UK), followed by a database search using the Mascot Search engine (Matrix Science, London, UK) against the NCBInr (National Centre for Biotechnology Information, Bethesda, MD, USA) database (ver. 20120224) with a Viridiplantae filter. The search parameters for precursor and product ion mass tolerance were $40 \mathrm{ppm}$ and $0.6 \mathrm{Da}$, respectively. Protein identification was performed using the Mascot search probability-based molecular weight search (MOWSE) score. The ion score was $-10 \times \log (\mathrm{P})$, in which P was the probability that the observed match was a random event. Peptides with a Mascot Score exceeding the threshold value corresponding to $a<5$ false-positive rate were considered to be positively identified.

\section{Conclusions}

Proteomic analysis showed that the cold temperature-induced dormancy breaking of rose seeds had an impact on the variability of the highest number of spots, and had more common spots with secondary dormancy then with the warm stratification. We found that the proteins generally were up-accumulated during dormancy breaking, but they were down-regulated during secondary dormancy induction. Functional analysis of identified proteins showed that induction of secondary dormancy caused storage protein consumption and a decrease in abundance of actin and metabolism enzymes. This can cause difficulty in the breaking of rose seed secondary dormancy. Results of the present study provide valuable information, revealing the general regulation of significant proteins following the varying temperatures of seed primary dormancy breaking and secondary dormancy induction. Overall, this data should enhance understanding of the processes associated with seed dormancy. The highlighting of potentially important proteins by proteomics provides researchers with starting points for further studies where the next step will be to examine the expression and regulation of the gene encoding the protein of interest, to incorporate it into the seed dormancy level testing.

Supplementary Materials: Supplementary materials can be found at http://www.mdpi.com/1422-0067/21/19/ 7008/s1. Figure S1. Experimental design of Rosa canina L. seed dormancy breaking by warm/cold stratification ( 16 weeks at $25^{\circ} \mathrm{C}$ followed by 22 weeks at $3{ }^{\circ} \mathrm{C}$ ) and germination tests (8 weeks at $3^{\circ} \mathrm{C}$ and $20{ }^{\circ} \mathrm{C}$ ). P1-4 terms of sample collections.

Author Contributions: Conceptualization, T.A.P., B.B.-B. and T.T.; methodology, T.A.P., B.B.-B. and T.T.; validation, T.A.P. and B.B.-B.; formal analysis, T.A.P., B.B.-B., P.C. and T.T.; investigation, T.A.P., B.B.-B., J.S., E.A.K. and A.M.S.; resources, T.A.P., B.B.-B., P.C. and T.T.; data curation, T.A.P.; writing-original draft preparation, T.A.P.; writing-review and editing, B.B.-B., J.S., P.C., T.T., E.A.K., and A.M.S.; visualization, T.A.P. and B.B.-B.; supervision, T.A.P. and T.T.; project administration, T.A.P. and T.T.; funding acquisition, T.A.P., P.C. and T.T. All authors have read and agreed to the published version of the manuscript.

Funding: This research was supported by the Institute of Dendrology, Polish Academy of Sciences, Kórnik, Poland.

Acknowledgments: The authors would like to thank Michał Dadlez's group from the Mass Spectrometry Laboratory, IBB PAS, Warsaw, Poland, for the MS analyses. The datasets generated and/or analyzed during the current study are available from the corresponding author upon reasonable request compliance with ethical standards.

Conflicts of Interest: The authors declare no conflict of interest. 


\section{References}

1. Kendall, S.; Penfield, S. Maternal and zygotic temperature signalling in the control of seed dormancy and germination. Seed Sci. Res. 2012, 22, S23-S29. [CrossRef]

2. Hilhorst, H.W.M. The regulation of secondary dormancy. The membrane hypothesis revisite. Seed Sci. Res. 1998, 8, 77-90. [CrossRef]

3. Finch-Savage, W.E.; Leubner-Metzger, G. Seed dormancy and the control of germination. N. Phytol. 2006, 171, 501-523. [CrossRef] [PubMed]

4. Footitt, S.; Huang, Z.; Clay, H.A.; Mead, A.; Finch-Savage, W.E. Temperature, light and nitrate sensing coordinate Arabidopsis seed dormancy cycling, resulting in winter and summer annual phenotypes. Plant. J. 2013, 74, 1003-1015. [CrossRef] [PubMed]

5. Murphey, M.; Kovach, K.; Elnacash, T.; He, H.; Bentsink, L.; Donohue, K. DOG1-imposed dormancy mediates germination responses to temperature cues. Environ. Exp. Bot. 2015, 112, 33-43. [CrossRef]

6. Soltani, E.; Baskin, J.M.; Baskin, C.C. A review of the relationship between primary and secondary dormancy, with reference to the volunteer crop weed oilseed rape (Brassica napus). Weed Res. 2019, 59, 5-14. [CrossRef]

7. Footitt, S.; Douterelo-Soler, I.; Clay, H.; Finch-Savage, W.E. Dormancy cycling in Arabidopsis seeds is controlled by seasonally distinct hormone-signaling pathways. Proc. Natl. Acad. Sci. USA 2011, 108, 20236-20241. [CrossRef]

8. Holdsworth, M.J.; Bentsink, L.; Soppe, W.J.J. Molecular networks regulating Arabidopsis seed maturation, after-ripening, dormancy and germination. N. Phytol. 2008, 179, 33-54. [CrossRef]

9. Staszak, A.M.; Rewers, M.; Sliwinska, E.; Klupczynska, E.A.; Pawlowski, T. DNA synthesis pattern, proteome, and ABA and GA signalling in developing seeds of Norway maple (Acer platanoides). Funct. Plant Biol. 2019, 46, 152-164. [CrossRef]

10. Basbouss-Serhal, I.; Leymarie, J.; Bailly, C. Fluctuation of Arabidopsis seed dormancy with relative humidity and temperature during dry storage. J. Exp. Bot. 2016, 67, 119-130. [CrossRef]

11. Chang, G.; Wang, C.; Kong, X.-X.; Chen, Q.; Yang, Y.; Hu, X. AFP2 as the novel regulator breaks high-temperature-induced seeds secondary dormancy through ABI5 and SOM in Arabidopsis thaliana. Biochem. Biophys. Res. Commun. 2018, 501, 232-238. [CrossRef] [PubMed]

12. Chiu, R.S.; Saleh, Y.; Gazzarrini, S. Inhibition of FUSCA3 degradation at high temperature is dependent on ABA signaling and is regulated by the ABA/GA ratio. Plant Signal. Behav. 2016, 11, e1247137. [CrossRef] [PubMed]

13. Ibarra, S.E.; Tognacca, R.S.; Dave, A.; Graham, I.A.; Sánchez, R.A.; Botto, J.F. Molecular mechanisms underlying the entrance in secondary dormancy of Arabidopsis seeds. Plant Cell Environ. 2015, 39, $213-221$. [CrossRef] [PubMed]

14. Kępczyński, J.; Bihun, M.; Kępczyñska, E. Implication of ethylene in the release of secondary dormancy in Amaranthus caudatus L. seeds by gibberellins or cytokinin. Plant Growth Regul. 2006, 48, 119-126. [CrossRef]

15. Kepczyński, J.; Cembrowska-Lech, D.; Sznigir, P. Interplay between nitric oxide, ethylene, and gibberellic acid regulating the release of Amaranthus retroflexus seed dormancy. Acta Physiol. Plant 2017, 39, 254. [CrossRef]

16. Li, Z.; Zhang, J.; Liu, Y.; Zhao, J.; Fu, J.; Ren, X.; Wang, G.; Wang, J. Exogenous auxin regulates multi-metabolic network and embryo development, controlling seed secondary dormancy and germination in Nicotiana tabacum L. BMC Plant Biol. 2016, 16, 41. [CrossRef]

17. Footitt, S.; Ölçer-Footitt, H.; Hambidge, A.J.; Finch-Savage, W.E. A laboratory simulation of Arabidopsis seed dormancy cycling provides new insight into its regulation by clock genes and the dormancy-related genes DOG1, MFT, CIPK23 and PHYA. Plant Cell Environ. 2017, 40, 1474-1486. [CrossRef]

18. Née, G.; Obeng-Hinneh, E.; Sarvari, P.; Nakabayashi, K.; Soppe, W.J. Secondary dormancy in Brassica napus is correlated with enhanced BnaDOG1 transcript levels. Seed Sci. Res. 2015, 25, 221-229. [CrossRef]

19. Chiang, G.C.K.; Barua, D.; Dittmar, E.; Kramer, E.M.; De Casas, R.R.; Donohue, K. Pleiotropy in the wild: The dormancy gene DOG1 exerts cascading control on life cycles. Evolution 2013, 67, 883-893. [CrossRef]

20. Suszka, B.; Bujarska-Borkowska, B. After-ripening, germination of seeds and seedling emergence of Rosa canina L. "Schmids Ideal" in relation to other rootstock selection of this species. Arboretum Kórnickie 1989, 34, $113-134$. 
21. Suszka, B.; Bujarska-Borkowska, B. Seed after-ripening, germination and seedling emergence of Rosa canina L. and some of its rootstock selection. Arboretum Kórnickie 1987, 32, 231-296.

22. Hilhorst, H.W. Definitions and hypotheses of seed dormancy. In Seed Development, Dormancy and Germination; Bradford, K.J., Nonogaki, H., Eds.; Wiley-Blackwell: Oxford, UK, 2007; pp. 50-71.

23. Edwards, B.; Burghardt, L.T.; Kovach, K.E.; Donohue, K. Canalization of seasonal phenology in the presence of developmental variation: Seed dormancy cycling in an annual weed. Integr. Comp. Biol. 2017, 57, 1021-1039. [CrossRef] [PubMed]

24. Liu, L.; Liu, F.; Chu, J.; Yi, X.; Fan, W.; Tang, T.; Chen, G.; Guo, Q.; Zhao, X. A transcriptome analysis reveals a role for the indole GLS-linked auxin biosynthesis in secondary dormancy in rapeseed (Brassica napus L.). BMC Plant Biol. 2019, 19, 264. [CrossRef] [PubMed]

25. Fei, H.; Tsang, E.; Cutler, A.J. Gene expression during seed maturation in Brassica napus in relation to the induction of secondary dormancy. Genomics 2007, 89, 419-428. [CrossRef] [PubMed]

26. Liu, F.; Zhao, X.; Zhang, L.; Tang, T.; Lu, C.; Chen, G.; Wang, X.; Bu, C.; Zhao, X. RNA-seq profiling the transcriptome of secondary seed dormancy in canola (Brassica napus L.). Chin. Sci. Bull. 2014, 59, 4341-4351. [CrossRef]

27. Ishihama, Y.; Oda, Y.; Tabata, T.; Sato, T.; Nagasu, T.; Rappsilber, J.; Mann, M. Exponentially modified Protein Abundance Index (emPAI) for estimation of absolute protein amount in proteomics by the number of sequenced peptides per protein. Mol. Cell. Proteom. 2005, 4, 1265-1272. [CrossRef]

28. Staszak, A.M.; Pawlowski, T.A. Forest tree research in post genomic era. Introduction to systems biology of broadleaves. Dendrobiology 2012, 68, 113-123.

29. Pawlowski, T.; Bergervoet, J.; Bino, R.; Groot, S.P.C. Cell cycle activity and $\beta$-tubulin accumulation during dormancy breaking of Acer platanoides L. seeds. Biol. Plant. 2004, 48, 211-218. [CrossRef]

30. Bentsink, L.; Koornneef, M. Seed dormancy and germination. Arab. Book 2008, 6, e0119. [CrossRef]

31. Née, G.; Xiang, Y.; Soppe, W.J. The release of dormancy, a wake-up call for seeds to germinate. Curr. Opin. Plant. Biol. 2017, 35, 8-14. [CrossRef]

32. Rodríguez, J.L.; De Diego, J.G.; Rodríguez, F.D.; Cervantes, E. Mitochondrial structures during seed germination and early seedling development in Arabidopsis thaliana. Biologia 2015, 70, 1019-1025. [CrossRef]

33. Czarna, M.; Kolodziejczak, M.; Janska, H. Mitochondrial proteome studies in seeds during germination. Proteomes 2016, 4, 19. [CrossRef] [PubMed]

34. Shotwell, M.A.; Afonso, C.; Davies, E.; Chesnut, R.S.; Larkins, B.A. Molecular characterization of oat seed globulins. Plant Physiol. 1988, 87, 698-704. [CrossRef] [PubMed]

35. Prewein, C.; Endemann, M.; Reinöhl, V.; Salaj, J.; Sunderlikova, V.; Wilhelm, E. Physiological and morphological characteristics during development of pedunculate oak (Quercus robur L.) zygotic embryos. Trees 2006, 20, 53-60. [CrossRef]

36. Gruis, D.F.; Selinger, D.A.; Curran, J.M.; Jung, R. Redundant proteolytic mechanisms process seed storage proteins in the absence of seed-type members of the vacuolar processing enzyme family of cysteine proteases. Plant Cell 2002, 14, 2863-2882. [CrossRef]

37. Krasuska, U.; Ciacka, K.; Orzechowski, S.; Fettke, J.; Bogatek, R.; Gniazdowska, A. Modification of the endogenous NO level influences apple embryos dormancy by alterations of nitrated and biotinylated protein patterns. Planta 2016, 244, 877-891. [CrossRef]

38. Kandasamy, M.K.; Gilliland, L.U.; McKinney, E.C.; Meagher, R.B. One plant actin isovariant, ACT7, is induced by auxin and required for normal callus formation. Plant Cell 2001, 13, 1541-1554. [CrossRef]

39. Gallardo, K.; Le Signor, C.; Vandekerckhove, J.; Thompson, R.D.; Burstin, J. Proteomics of Medicago truncatula seed development establishes the time frame of diverse metabolic processes related to reserve accumulation. Plant Physiol. 2003, 133, 664-682. [CrossRef]

40. Deng, Z.J.; Hu, X.F.; Ai, X.R.; Yao, L.; Deng, S.M.; Pu, X.; Song, S.Q. Dormancy release of Cotinus coggygria seeds under a pre-cold moist stratification: An endogenous abscisic acid/gibberellic acid and comparative proteomic analysis. N. For. 2016, 47, 105-118. [CrossRef]

41. Díaz-Camino, C.; Conde, R.; Ovsenek, N.; Villanueva, M.A. Actin expression is induced and three isoforms are differentially expressed during germination in Zea mays. J. Exp. Bot. 2005, 56, 557-565. [CrossRef] 
42. De Farias, E.T.; Da Silva, E.A.A.; Toorop, P.E.; Bewley, J.D.; Hilhorst, H.W.M. Expression studies in the embryo and in the micropylar endosperm of germinating coffee (Coffea arabica cv. Rubi) seeds. Plant Growth Regul. 2015, 75, 575-581. [CrossRef]

43. Gilliland, L.U.; Pawloski, L.C.; Kandasamy, M.K.; Meagher, R.B. Arabidopsis actin gene ACT7 plays an essential role in germination and root growth. Plant J. 2003, 33, 319-328. [CrossRef] [PubMed]

44. Park, M.R.; Wang, Y.-H.; Hasenstein, K.H. Profiling gene expression in germinating Brassica roots. Plant. Mol. Biol. Rep. 2014, 32, 541-548. [CrossRef] [PubMed]

45. Wang, W.-Q.; Song, B.-Y.; Deng, Z.-J.; Wang, Y.; Liu, S.-J.; Møller, I.M.; Song, S.-Q. Proteomic analysis of lettuce seed germination and thermoinhibition by sampling of individual seeds at germination and removal of storage proteins by polyethylene glycol fractionation. Plant Physiol. 2015, 167, 1332-1350. [CrossRef]

46. Haferkamp, I.; Fernie, A.R.; Neuhaus, H.E. Adenine nucleotide transport in plants: Much more than a mitochondrial issue. Trends Plant Sci. 2011, 16, 507-515. [CrossRef] [PubMed]

47. Da Fonseca-Pereira, P.; Neri-Silva, R.; Cavalcanti, J.H.F.; Brito, D.S.; Weber, A.P.; Araújo, W.L.; Nunes-Nesi, A. Data-mining bioinformatics: Connecting adenylate transport and metabolic responses to stress. Trends Plant Sci. 2018, 23, 961-974. [CrossRef] [PubMed]

48. Hoffmann, C.; Plocharski, B.; Haferkamp, I.; Leroch, M.; Ewald, R.; Bauwe, H.; Riemer, J.; Herrmann, J.M.; Neuhaus, H.E. From endoplasmic reticulum to mitochondria: Absence of the Arabidopsis ATP antiporter endoplasmic reticulum adenylate transporter1 perturbs photorespiration. Plant Cell 2013, 25, 2647-2660. [CrossRef] [PubMed]

49. Leroch, M.; Neuhaus, H.E.; Kirchberger, S.; Zimmermann, S.; Melzer, M.; Gerhold, J.; Tjaden, J. Identification of a Novel adenine nucleotide transporter in the endoplasmic reticulum of Arabidopsis. Plant Cell 2008, 20, 438-451. [CrossRef]

50. Fu, S.-F.; Chen, P.-Y.; Nguyen, Q.T.T.; Huang, L.-Y.; Zeng, G.-R.; Huang, T.-L.; Lin, C.-Y.; Huang, H. Transcriptome profiling of genes and pathways associated with arsenic toxicity and tolerance in Arabidopsis. BMC Plant Biol. 2014, 14, 94. [CrossRef]

51. Palmieri, F.; Pierri, C.L.; De Grassi, A.; Nunes-Nesi, A.; Fernie, A.R. Evolution, structure and function of mitochondrial carriers: A review with new insights. Plant J. 2011, 66, 161-181. [CrossRef]

52. Lo, Y.-S.; Cheng, N.; Hsiao, L.-J.; Annamalai, A.; Jauh, G.-Y.; Wen, T.-N.; Dai, H.; Chiang, K.-S. Actin in mung bean mitochondria and implications for its function. Plant Cell 2011, 23, 3727-3744. [CrossRef]

53. Senior, A.E.; Nadanaciva, S.; Weber, J. The molecular mechanism of ATP synthesis by F1F0-ATP synthase. Biochim. Biophys. Acta Bioenerg. 2002, 1553, 188-211. [CrossRef]

54. Zaynab, M.; Pan, D.; Noman, A.; Fatima, M.; Abbas, S.; Umair, M.; Sharif, Y.; Chen, S.-P.; Chen, W. Transcriptome approach to address low seed germination in Cyclobalanopsis gilva to save forest ecology. Biochem. Syst. Ecol. 2018, 81, 62-69. [CrossRef]

55. He, M.; Zhu, C.; Dong, K.; Zhang, T.; Cheng, Z.; Li, J.; Yan, Y. Comparative proteome analysis of embryo and endosperm reveals central differential expression proteins involved in wheat seed germination. BMC Plant Biol. 2015, 15, 97. [CrossRef] [PubMed]

56. Pawlowski, T. Proteomics of European beech (Fagus sylvatica L.) seed dormancy breaking: Influence of abscisic and gibberellic acids. Proteomics 2007, 7, 2246-2257. [CrossRef] [PubMed]

57. Pawlowski, T. Proteome analysis of Norway maple (Acer platanoides L.) seeds dormancy breaking and germination: Influence of abscisic and gibberellic acids. BMC Plant Biol. 2009, 9, 48. [CrossRef]

58. Pawlowski, T.; Staszak, A.M. Analysis of the embryo proteome of sycamore (Acer pseudoplatanus L.) seeds reveals a distinct class of proteins regulating dormancy release. J. Plant Physiol. 2016, 195, 9-22. [CrossRef]

59. Wojtyla, Ł.; Kosmala, A.; Garnczarska, M. Lupine embryo axes under salinity stress. II. Mitochondrial proteome response. Acta Physiol. Plant 2013, 35, 2383-2392. [CrossRef]

60. Yin, G.; Sun, H.; Xin, X.; Qin, G.; Liang, Z.; Jing, X. Mitochondrial damage in the soybean seed axis during imbibition at chilling temperatures. Plant Cell Physiol. 2009, 50, 1305-1318. [CrossRef]

61. Pawlowski, T. Proteomic approach to analyze dormancy breaking of tree seeds. Plant. Mol. Biol. 2010, 73, 15-25. [CrossRef]

62. Bradford, M.M. A rapid and sensitive method for the quantitation of microgram quantities of protein utilizing the principle of protein-dye binding. Anal. Biochem. 1976, 72, 248-254. [CrossRef] 
63. Candiano, G.; Bruschi, M.; Musante, L.; Santucci, L.; Ghiggeri, G.M.; Carnemolla, B.; Orecchia, P.; Zardi, L.; Righetti, P.G. Blue silver: A very sensitive colloidal Coomassie G-250 staining for proteome analysis. Electrophoresis 2004, 25, 1327-1333. [CrossRef] [PubMed]

64. Pawlowski, T.; Staszak, A.M.; Karolewski, P.; Giertych, M.J. Plant development reprogramming by cynipid gall wasp: Proteomic analysis. Acta Physiol. Plant 2017, 39, 114. [CrossRef] 